\title{
From Zero to Hero: Leading with Muhammadiyah Educational Philosophy
}

\author{
$1^{\text {st }}$ Abin Suarsa \\ STIE Muhammadiyah Bandung, \\ Universitas Muhammadiyah Bandung \\ Indonesia \\ abinsuarsa@gmail.com
}

\author{
$2^{\text {nd }}$ Yuniati Yuniati \\ STIE Muhammadiyah Bandung, \\ Universitas Muhammadiyah Bandung \\ Indonesia
}

\author{
$3^{\text {rd }}$ Toto Sugihyanto \\ STIE Muhammadiyah Bandung, \\ Universitas Muhammadiyah Bandung \\ Indonesia
}

\begin{abstract}
This study aims to explore the success of Yogyakartas Muhammadiyah Boarding School (MBS) in managing human resources so that it becomes a leading school in a relatively short time with the support of small financial resources. Phenomenology is used as a research method with founders, top management and employees as informants. This study found that there are two phases of human resource management, the establishment phase and the school development phase. The philosophy of Muhammadiyahs education supported by the ideology of "Ikhlas" plays an important role in the human resource management practice. Routine "Pengajian" as a tool to transform ideology. Management replies "Ikhlas" with facilities as a reward that has an impact on the quality of human resources. The practice of educational management based on Muhammadiyahs educational philosophy makes MBS From Zero to Hero and as a national reference school.
\end{abstract}

Keywords-Leading, Muhammadiyah, Educational, Philosophy

\section{INTRODUCTION}

Integralistic which is Muhammadiyah's educational philosophy which has been formulated in the 46th Conference (Muhammadiyah First Century Conference) in Yogyakarta on July 3-8, 2010 explicitly states that "Muhammadiyah education is the preparation of an environment that enables a person to grow as a person who is aware of the presence of Allah Almighty, and mastered science, technology, and art (science and technology) " [1].

The concept of education offered by Muhammadiyah Boarding School (MBS) Yogyakarta is a concept that meets the dimensions of reason, heart and skill. An integrated curriculum between local content and national curriculum and supported by professionalism of management [2]. Anis Baswedan was also impressed with the concept of PPM MBS Yogyakarta "I admire the educational concept promoted by MBS, which creates a fun school for its students, this can be clearly illustrated through the cheerfulness of the students after working on UN questions, not there are burdens or difficulties on their faces, "he further added" It is fitting for schools to be like that, to become a pleasant learning park, no longer a scary place " [3]
The purpose of this study was to determine the Management of Resource Management in the Establishment Phase, Development Phase, and implementation of Muhammadiyah's Educational Philosophy in all phases so as to make PPM MBS Yogyakarta the Leading.

\section{LITERATURE REVIEW}

\section{A. From Zero to Hero}

The concept of zero according to Bob Sadino means it means giving up hope. This means that each step without the lure, without creating important expectations, still acts and performs as a form of feeling grateful for what Allah has given. Zero is depicted as an empty circle, a manifestation of complete faith, resigned without prejudice and fear. Zero means "Total Surrender", a unanimous faith in what will happen in the future, belief in miracles and paths that we have never thought of at all [4].

\section{B. Muhammadiyah's Educational Philosophy}

Education is a strategic field as a charitable effort in the Muhammadiyah organization which began to exist and developed rapidly since 1911 K. H Ahmad Dahlan established the Muhammadiyah cottage. A fact of the ability to manage educational and continuing institutions which has now reached more than a century. A solid foundation for achieving the sustainability of educational institutions is called the educational philosophy [1].

K.H Ahmad Dahlan succeeded in instilling a solid footing as the values of Muhammadiyah's educational struggle based on passion and creative action that always referred to the values of the Qur'an and Sunnah. Sincere, cooperation, spirit of tajdid, siding with the dhu'afa 'and mustadh'afin and the balance between common sense and purity of heart. Creative actions that integrate religious knowledge with other sciences as long as they can.

Muhammadiyah's educational philosophy that has been formulated as contained in the Tanfidz Decree of the First Century Muhammadiyah Conference in 2010 which is a movement, ideas and ideas of K.H Ahmad Dahlan.

K. H. Ahmad Dahlan is a type of man of action who always gives actions and reactions to the educational 
movement he initiated. His last speech entitled "The Rope of Human Life" was the red thread of his thoughts that showed the direction of Muhammadiyah's educational philosophy. From the speech it is implied; (a) The highest knowledge is knowledge about the unity of life that can be achieved with a critical and open attitude with common sense and istiqomah to the truth of the mind that is based on a pure heart, (b). Intellect becomes the power to fulfill the basic necessities of human life, (c) logic or logic is the highest education for reason that will only be achieved if it relies on the guidance of Allah.

From the foregoing thoughts, K.H Ahmad Dahlan initiated the birth of the Muhammadiyah educational model that is capable of facing challenges. Integralistic concepts between ultimate truths that open wide rationality through Islamic teachings, call for ijtihad, reject imitation and return to the Qur'an and Sunnah. The ideals he initiated will give birth to new human beings who are able to appear as "ulama-intellect" or "intellect-ulama" as a translation of his saying "Dadijo Kjai sing kamadjuan, and there are your members to welcome the Muhammadiyah kanggo kanggo Muhammdijah". The emphasis on the progressive character of Islam provides a dynamic force for civilization when dealing with the times.

\section{Educational Management and Educational Philosophy of Muhammadiyah}

Educational management is an ongoing process carried out by educational organizations through the functionalization of these management elements. Wherein there are efforts made to influence each other, direct each other and supervise each other so that all activities and performance of educational organizations can be achieved in accordance with the objectives of the establishment of educational institutions [5]. Educational management is a process that is carried out consciously and planned to create an atmosphere of learning and learning process and achieve educational goals starting from planning, organizing, implementing and controlling using human resources and other resources to achieve organizational goals [6].

From the above understanding it can be concluded that education management is a process of a management system that will create a learning process in order to achieve educational goals.

Education management starts from the establishment, development, until the plan for future development. The establishment phase is the period in which educational institutions begin by planning, organization, implementation and supervision. At this time is a difficult time because it requires a lot of resources. At this time the founders' commitment, financial resources, infrastructure, human resources, and convincing the guardian of the students needed to register their children as students.

If it is associated with Muhammadiyah's educational philosophy and all parties, both founders and managers, will understand the educational philosophy, then everything will be resolved. Sincere work, always creative and supported by commitments from all parties, as well as providing an integrated educational concept that reflects quality will give confidence to student guardians.

The development phase is a period where management patterns have been formed and where at this stage demands quality improvement in all fields. At this time maintaining quality has a very big challenge. The greater the community's trust, the higher the demand for quality education must be responded by management.

Creative attitude and sincerity and supported by management commitment will provide convenience. Flexibility Muhammadiyah's educational philosophy, which holds all stakeholders, will be able to answer all challenges during development.

\section{RESEARCH METHOD}

In this study, the method used is a qualitative method. A qualitative method with a phenomenological approach which is a constructivist or naturalistic approach [7].

There are two fundamental reasons for the use of a qualitative approach in this study, namely: first, to explore and understand the meaning of the object of research from individuals or groups that are ascribed to social or humanitarian problems. Second, the acquisition of data can be more complete, more profound, and reliable, as well as all events in a social context that include feelings, norms, beliefs, habits, mental attitudes, and cultures adhered to by individuals and groups of individuals can be found [8].

Informants in this study were subjects directly involved in the establishment and management, experts in Muhammadiyah education philosophy, and MBS users in Yogyakarta. Based on the representation of informants, this study uses an insider's perspective (EMIK).

TABLE I. LIST OF INFORMANT NAMES

\begin{tabular}{|c|l|l|}
\hline No & \multicolumn{1}{|c|}{ Name } & \multicolumn{1}{|c|}{ Position } \\
\hline 1 & Ust. H.M Nashirul Ahsan, Lc & PCM Prambanan / Founder \\
\hline 2 & Ust. Fajar Shadiq, Lc & $\begin{array}{l}\text { Director of PPM Muhammadiyah } \\
\text { Boarding School }\end{array}$ \\
\hline 3 & Ust. Rahmat & Head of HRD \\
\hline 4 & Ust. Faqihhuddin, Lc & Head of Kemadhadan Putra \\
\hline 5 & Ust. Septian & Staff of Public Relation \\
\hline 6 & Mr. Darminto & Head of Security \\
\hline 7 & Mr. Andi & Member of Security \\
\hline
\end{tabular}

IV. RESULT AND DISCUSSION

\section{A. Establishment Phase}

The journey to form an MBS was not as easy as planned. Starting with the development plan of Prambanan 1 Muhammadiyah Middle School which ran aground because of differences in views and then turned around to form the Islamic Boarding School. But because of a strong intention, Ust Nashir as Informant said: "... and already wet with the intention to form a boarding school .." then the Islamic Boarding School stand independently. MBS was founded by people who have a strong will. Ust Sadiq said: "... strong will will defeat ability, and strong will will always get its way ..."

The establishment of MBS is not only based on strong will, but also with Concept. Ust Fajar Sadiq said: "... MBS is selling the concept ...", MBS offers an educational concept that is the balance of Islamic Boarding School curriculum and general curriculum. This concept was the mainstay of MBS at the beginning of its establishment. Ust Fajar Sadik and Ust Nashirul said: "... at the beginning of the establishment of MBS it had no achievements, so yes MBS 
offered a concept ...". The concept of balance is contained in one of the missions "Organizing Integral Pesantren Education which Integrates Pesantren Education Curriculum and National Education Curriculum" and becomes one of the Identities of MBS Yogyakarta "MBS as a Make for Intellectual Ulema and Intellectual Ulama".

By carrying out and offering the concept of integration of the Islamic boarding school curriculum with the national curriculum, it provides significant logical consequences for Human Resources. Ust Fajar Sadiq said: "... the consequences are very heavy on HR especially those based on sharia ...". To anticipate the shortage of human resources based on shari'a, the financing of existing human resources is carried out by the founders who have the capacity and background of the pesantren.

Another very significant consequence in HR management is financial factors. The founders tried to provide guidance to existing human resources, Ust Nashirul said: "... we did the financing so as to cause militancy...". This HR militancy became the initial capital in the management of Islamic boarding schools. Mr. Darmanto said: " from the beginning we joined the study often which makes me feel more working with sincerity and comfort...". This militancy is what makes HR work sincerely, work that holds on to finance is not everything, working to find His pleasure. Ust Nashirul said: "....we established MBS from Zero Rupiah even minus....".

With the management of human resources at this phase of the establishment that produces HR who are militant and sincere in working, the obstacles in fulfilling Human Resources in managing boarding schools can be overcome.

Muhammadiyah's educational philosophy that has been formulated as contained in the Tanfidz Decree of the First Century Muhammadiyah Conference in 2010 which is a movement, ideas and ideas of K.H Ahmad Dahlan.

His last speech entitled "The Rope of Human Life" was the red thread of his thoughts that showed the direction of Muhammadiyah's educational philosophy. From the speech it is implied; (a) The highest knowledge is knowledge about the unity of life that can be achieved with a critical and open attitude with common sense and istiqomah to the truth of the mind that is based on a pure heart, (b). Intellect becomes the power to fulfill basic needs of human life, (c) Mantiq or logic is the highest education for reason that will only be achieved if it relies on the guidance of Allah.

From the above philosophy, PPM Muhammadiyah Boarding School in the founding phase has clearly implemented an educational philosophy by carrying out and offering "Intergralistic Concepts of Islamic Boarding School Curriculum with National Curriculum" which will create "MBS as a make for Intellectual Ulema and Ulama Intellectual". This clear and measurable concept has received significant response and full support from various groups such as; Dr. H. Agung Danarto, M.Ag as Chairman of the Yogyakarta Muhammadiyah Regional Board, Prof., Dr. Amin Rais, MA, Prof., Dr. Yunahar Ilyas, Prof., Dr. Hj. Siti Chamamah Suratno, and Deputy Regent Drs. Sri Purnomo M.Sc.

\section{B. Development Phase}

In this phase the community's response to MBS has been strongly felt by the community's interest in making MBS as a school for their sons and daughters. In the fifth year the surge in the number of students began to be felt, and of course this greatly affected the number and quality of Human Resources who supported it.

To maintain public confidence in MBS, inevitably schools must balance with the trust of the community. One thing that must be considered is the number of educators and non-educators. In addition, the quality of educators and non-educators continues to be improved.

In the development phase, HR management in order to improve the quality of existing HR and add new HR to meet needs.

The recruitment process is carried out when there is a need for human resources because the number of students is increasing. The recruitment process from admission, selection process to announcement of admission is no different from other schools.

There is an interesting thing in the selection process, namely how to see prospective employees with their motivation to join MBS. MBS stipulates that the motivation of prospective employees must not only look at the material as an objective. Ust Fajar Sadiq said: "... in the recruitment process, if prospective employees only talk about the material then it will definitely not be accepted ...". This is also supported by Ust Nashirul's statement "... we do not reject the material, but if the purpose of joining is only for the material without the aim of fighting in the world of education, then it is not good ...". In line with what was conveyed by Ust Rahmat "... what was seen when at the interview stage was the atitude of prospective employees, $\ldots$ if the prospective employee had calculated then, it will definitely not be accepted ..." BPH so the consistency of the answers of prospective employees will be seen.

Coaching is done for new employees before being deployed directly at the learning process stage. Ust Rahmat said: "... the current generation is more pragmatic, prospective employees see MBS is already large, they see the process and results, they never know the struggle to establish MBS..." so that it needs an ideological guidance for employees to clearly understand the direction and goals of the organization's struggle. This will create a sense that working in MBS must be sincere, not just thinking about the material but is a worship that will get reward.

One of the activities that must be passed by new employees in addition to the standard of fostering employees in the Muhammadiyah organization is the deployment of them to do internships in Muhammadiyah schools that are very difficult in material, facilities and resources. Ust Fajar and Ust Fajar said: "... new employees will be placed in Muhammadiyah schools that are lacking ...".

This apprenticeship was carried out for two weeks, and then required to make a report on the results of the activity, Ust Septian said: "... I participated in apprenticeship for two weeks at a school that was very short and at the end of the activity was required to make a report ...". The purpose of this activity is to open the minds of new employees that 
MBS has experienced something similar to that experienced by the Muhammadiyah schools. Ust Fajar and Ust Rahmat said: "... they will feel how difficult the schools that are lacking, and the weight of the school's struggle to achieve establishment ...". They will realize that the process of becoming a MBS now is not easy, it requires hard work, sincere work, not just thinking about the material.

Implanting this ideology is important in employees to ensure that employees will work on the tracks that have been set. This ideology will create employee awareness about the importance of working sincerely. Ust Rahmat said: "... it is necessary to instill an ideology in employees to work sincerely ...".

This activity is carried out routinely at least once a week. All employees including leaders without exception must follow it, Ust Nasir, Ust Fajar, Ust Rahmat, and Ust Faqih said "... all leaders must follow routine recitation activities ...". Including employees are also required to attend the event, Ust Septian, Mr. Darmanto, and Mr. Andi said: "... we always attend weekly recitation activities, every Thursday ...".

In the recitation program it is always conveyed repeatedly about the importance of sincerity at work, so that it will be embedded in employees. Ust Fajar said: "... psychologically if something is said repeatedly, slowly it will be planted with sincerity in the employee ...".

The recitation is a means, and the recitation must be carried out routinely, the recitation is the spirit of Muhammadiyah, Ust Nashirul said: "... the spirit of the Muhammadiyah is recitation, it must be routine at least once a week, that is minimal ... if less than that Muhammadiyah is nothing ...".

Sincerity at work that has been embedded in employees must be responded by management to be managed properly. Ust Fajar and Ust Rahmat said: "... sincerity in employees must be responded by management to be their sincerity...".

\section{CONCLUSION}

From the research results above, it can be concluded as follows:

- Human Resources Management Establishment Phase; by carrying out and offering the concept of integration of Islamic boarding school curriculum with the national curriculum has significant logical consequences for Human Resources. To anticipate the shortage of human resources based on shari'a, the financing of existing human resources is carried out by the founders who have the capacity and background of the pesantren. Another very significant consequence in HR management is financial factors. The founders tried to foster existing HR into militant HR and became the initial capital in managing the Islamic Boarding School. This militancy is what makes HR work sincerely, work that holds on to finance is not everything, working to find His pleasure.

- Management of Human Resources Development Development Phase: In the development phase, HR management is in the framework of improving the quality of existing HR and adding new HR to meet needs. The recruitment process is carried out when there is a need for human resources because the number of students is increasing. The recruitment process from admission, selection process to announcement of admission is no different from other schools. Coaching is done for new employees before being deployed directly at the learning process stage. One of the activities that must be passed by new employees in addition to the standard of fostering employees in the Muhammadiyah organization is the deployment of them to do internships in Muhammadiyah schools that are very difficult in material, facilities and resources. The purpose of this activity is to open the minds of new employees that MBS has experienced something similar to that experienced by the Muhammadiyah schools. They will realize that the process of becoming a MBS now is not easy, it requires hard work, sincere work, not just thinking about the material.

\section{ACKNOWLEDGMENTS}

Thank you to the Higher Education Research and Development Council (DIKTILITBANG) Muhammadiyah Central Board for providing research grants. Hopefully the results of this study will benefit the people.

\section{REFERENCES}

[1] D. Siddik, Filosofi Pendidikan Muhammadiyah. In A. Daulay \& J. Ja'far (Eds), Falsafah Pendidikan Islam: Menguak Nilai-Nilai Pendidikan Dalam Tradisi Islam, Perdana Publishing, 2015.

[2] S. Z. Khasanah and Z. Arifin, "Implementasi Pengembangan Kurikulum Di Smp Muhammadiyah Boarding School (MBS)," TADRIS: Jurnal Pendidikan Islam, vol. 12, no. 1, pp. 79-91, 2017.

[3] M. B. School, "Pondok Pesantren Modern Muhammadiyah Bording School Yogyakarta," PPM MBS Yogyakarta, 3 August 2017. [Online]. Available: https://mbs.sch.id/2017/08/03/anis-baswedankagumi-konsep-pendidikan-di-mbs/. [Accessed 19 March 2019].

[4] J. Setiabudi, "Young Entrepreneur Academy," YEA-Indonesia, 1 April 2015. [Online]. Available: http://yeaindonesia.com/2015/04/01/from-zero-to-hero/. [Accessed 24 March 2019].

[5] H. Hikmat, Manajemen Pendidikan, Bandung: Pustaka Setia, 2011.

[6] E. Maria and E. Sediyono, "Pengembangan Model Manajemen Pembelajaran Berbasis TIK di Sekolah Dasar," Kelola: Jurnal Manajemen Pendidikan, vol. 4, no. 1, pp. 59-71, 2017.

[7] L. Fauji, M. Sudarma and M. Achsin, "Penerapan Sistem Pengendalian Mutu dalam Meningkatkan Kualitas Audit," Jurnal Akuntansi Multiparadigma, vol. 6, no. 1, pp. 38-52, 2015.

[8] J. W. Creswell, Research Design: Pendekatan Kualitatif, Kuantitatif, dan Mixed, Yogyakarta: PT Pustaka Pelajar, 2010. 